\title{
Physico-Chemical Characterization of an Artificial Pond to Control the Eutrophication Process: A Case Study
}

\author{
Sameer Al-Asheh ${ }^{1}$, Hani Abu Qdais ${ }^{2}$, Adnan Alquraishi ${ }^{3}$, Osama Husain ${ }^{1}$, Ismail Sadoon ${ }^{4}$ \\ Department of Chemical Engineering, American University of Sharjah, UAE ${ }^{1}$ \\ Department of Civil Engineering, Jordan University of Science and Technology, Irbid, Jordan ${ }^{2}$ \\ Department of Biological Sciences, Jordan University of Science and Technology, Irbid, Jordan ${ }^{3}$ \\ Department of Applied Biology, University of Sharjah, Sharjah-United Arab Emirates ${ }^{4}$
}

\begin{abstract}
This study aimed at investigating the physical and chemical parameters prevailed in artificial pond at Jordan University of Science and Technology (JUST) campus over a period of twelve months, in order to identify the main sources for the increase in nitrate and phosphate levels and their role in blooming growth of algae in this reservoir. Six sampling stations were selected for the investigation depending on water sources inlet and water outlet. All samples were tested for physical and chemical characterizations according to the standard methods. Parameters such as temperature, $\mathrm{pH}$, water transparency, dissolved oxygen (DO), electrical conductivity (EC), and total dissolved solids (TDS) were measured on site. While other parameters such as nitrate, phosphate, chloride, chemical oxygen demand (COD), alkalinity, heavy metals including ( $\mathrm{Fe}, \mathrm{Mn}, \mathrm{Zn}$, and $\mathrm{Cu}$ ), and soft metals ( $\mathrm{Na}$ and $\mathrm{K}$ ) were measured in the laboratory. Results of $\mathrm{PO}_{4}$ and $\mathrm{NO}_{3}$ values for all stations lie within both WHO and Jordanian guidelines. Sometimes in winter season both effluents from Wadi Hassan wastewater treatment plant and JUST wastewater treatment plant reach the upper permissible limit for phosphate. For NO3 values for some cases; the input from JUST wastewater treatment plant exceeded the acceptable limits. Measurements of all others parameters, for all stations, were within permissible limits and do not have negative impact on water quality of the pond.
\end{abstract}

Keywords: Artificial pond, Eutrophication, Nitrate, Phosphate, JUST.

\section{INTRODUCTION}

Water quality is one of the most important factors concerning public health. Water quality is not deteriorated merely by industrial and municipal effluents but also by organisms such as bacteria, algae and cyano-bacteria. Reservoir water quality is controlled to a large extent by the quantity and quality of external nutrients loading. Knowledge of the loading rates of nutrients can shed some light on the potential productivity of the reservoir. Eutrophication, or over enrichment with nutrients, is an environmental issue of concern for wetlands, streams, rivers, lakes, and reservoirs, which can cause a range of effects on the quality of receiving waters worldwide. These inland surface waters are embedded in landscapes that vary extensively in their natural fertility [1]. In addition, the supply rates of two key plant nutrients nitrogen $(\mathrm{N})$ and phosphorus $(\mathrm{P})$ - can be greatly increased by human activities. Nutrients, derived directly or indirectly from human activities, can cause rapid and sometimes extreme eutrophication in previously infertile waters.

Eutrophication of the aquatic environment due to human activities has giving rise to a variety of problems in fresh water supplies. For the phototrophic cyanobacteria, light serves as the sole source of energy, and the impact of light as a growth factor causing the development of cyanobacterial blooms has been clearly established [2, 3].Besides the need for light in photosynthetic carbon fixation, cells also require substantial amounts of phosphorus and nitrogen. Nitrogen and phosphorus have been implicated as the major nutrients responsible for eutrophication, starting with Neumann [4] stating that: "Nitrogen and phosphorus are the most important nutrients" in the eutrophication cycle. Sawyer [5] discussed the importance of these nutrients and their relationship to eutrophication. Phosphorus was identified as a nutrient likely to be limiting in many, if not most, freshwater environments. Compared to phosphorus, studies on the role of nitrogen as a growth limiting factor in most fresh water ecosystems are few; this is probably due to the fact that phosphorus is growth-limiting in these environments. However, in lakes subjected to increased eutrophication due to increased phosphorus levels, nitrogen may become the growth-limiting nutrient $[3,6]$. Spears et al. [7] studied the effects of light and temperature on nutrient cycling (silica, nitrogen and phosphorus) between sediments and water in a shallow eutrophic lake and consequent effects on water column nutrient stoichiometry using a series of intact sediment core incubation experiments. His study concluded that a significant decrease in $\mathrm{P}$ release was observed under light conditions in the longer incubation experiments most probably as a result of photosynthetic maintenance of the dissolved oxygen and $\mathrm{pH}$ conditions at the sediment surface $(\mathrm{P})$ and direct uptake by algae $(\mathrm{P})$, altering the 
transport of nutrients across the sediment-water interface. Beutel et al. [8] evaluated the concentrations of key nutrients and metals in samples of lake water overlaying sediments under both aerobic and anaerobic conditions in chambers containing undisturbed sediment-water interface. Correlation analysis elucidated a number of interactions between compounds. Phosphate correlated significantly with iron during all incubation phases, suggesting that phosphorus cycling was controlled by iron. In water affected by human made effluents, such as that of the constructed pond at Jordan University of Science and Technology (JUST), an algal bloom is expected to happen and thus may cause problems affecting water quality resulting from excessive load of nutrients, calm conditions and less water inflow.

The purpose of this work is to investigate the effect of different physical and chemical factors on the phytoplankton organisms which grow in the artificial constructed pond reservoir at JUST which in turn affect both water quality and its safety for domestic uses. The study also monitors all possible environmental parameters that play a role in making water favorable for algal blooms, and attempts to find a possible control procedure that would lead to a useful monitoring plan for less polluted water. Specific objectives include identification of the main sources for the increase in nitrate and phosphate levels and the growth of algae in JUST pond.

\section{METHODOLOGY}

\section{A. Area of study}

The campus of Jordan University of Science and technology (JUST) is located near Ramtha City, $70 \mathrm{kms}$ north of Amman, the capital of Jordan, and $20 \mathrm{kms}$ east of Irbid City. The main campus extends over $11 \mathrm{k} \mathrm{m}^{2}$ and surrounded by a green cover of around 135,000 trees. The artificial constructed pond (Figure 1) is located in the middle part of JUST campus.

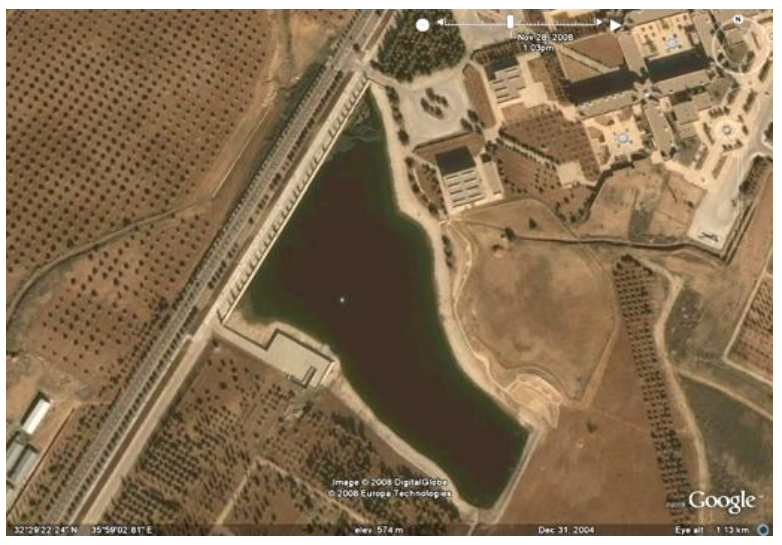

Figure 1.Arial view of JUST pond with algal plume accumulation at the edges of the pond

The riprap area of the pond is about $44,500 \mathrm{~m}^{2}$, while at water maximum and water minimum it is about $38,000 \mathrm{~m}^{2}$ and $16,000 \mathrm{~m}^{2}$, respectively. Maximum and minimum capacities of the pond are about 132,000 and $22,500 \mathrm{~m}^{3}$, respectively; its maximum depth is about $7.11 \mathrm{~m}$. This reservoir was originally constructed to store water for irrigation of different areas in the campus. The reservoir water comes mainly from both Wadi Hassan and JUST wastewater treatment plants and partially from precipitation. Wadi Hassan is a wastewater treatment plant located close to the campus, about $3 \mathrm{~km}$ away, which brings its treated water to JUST's lake through pipelines under contract with the university. JUST wastewater treatment plant is located at the south part of the campus.

\section{B. Sampling}

Six sampling stations have been selected for investigation. Station I represents the open area located at the middle of the pond; this station is reached by using Kayak boat in order to collect samples for the investigation of vertical distribution of the parameters under consideration. Deeper samples at station I were collected from 0,1 and then every $1 \mathrm{~m}$ to the bottom (maximum depth is $5 \mathrm{~m}$ from the surface). Station II is the closest to the edge of the pond. Station III is the input site from Wadi Hassan wastewater treatment plant inside the plant. Station IV is the input site from Wadi Hassan wastewater treatment plant inside the university. Station V is the input from JUST wastewater treatment plant. Station VI is the output from the pond. Water samples have been collected monthly from each station during the study period that last for one complete cycle from July 2009 to the end August 2010.

Nansen 1 L Water Sampler (Germany) was used to collect samples at different depths. The water samples were stored in polyethylene bottles; the bottles were washed previously with both distilled water sampled water prior to sampling. The water samples were transported to the laboratory, and subjected to further analysis. The physical analysis of water samples was conducted on site.

\section{Sample Analysis}

In the laboratory, the interstitial water samples were centrifuged at $200 \mathrm{rpm}$ for $1 \mathrm{~min}$ (Medifuge 1215, Heraeus Christ, USA). Water samples were first filtered using Whatman filters. The analyses were performed at the same day of sampling. The following analytical methods have been carried out according to the standard methods for the examination of water and wastewater (Eaton et al., 2005).

\section{Physical analysis}

Water transparency was measured using a $21 \mathrm{~cm}$ Secchi disc. Both water surface and atmospheric temperatures were measured using glass thermometer. The $\mathrm{pH}$ was measured using portable $\mathrm{pH}$ Meter (WTW, Germany). Dissolved Oxygen (DO) was measured using portable DO Meter (Milwaukee company, Italy). Electrical Conductivity (EC) was measured using portable EC Meter (Jencocompany, USA). Total Dissolved Solids (TDS) was measured using portable TDS Meter (Myrolcompany, USA).

\section{E. Chemical analysis}

Nitrate was measured using Hach Lange VS-spectrometer (GMBH, DR-5000, Germany) with corresponding nitrate kit.

Phosphorus, chloride, and chemical oxygen demand (COD) were measured using Photometer Photolab S12-A (WTW 250026 KWT, Germany). Such device is based on 
pre-prepared kits for a particular component to be analyzed.

Heavy metals including $\mathrm{Fe}, \mathrm{Mn}, \mathrm{Zn}$, and $\mathrm{Cu}$ as well as other metals such as $\mathrm{Na}$ and $\mathrm{K}$ were measured using Atomic Absorption Spectrophotometer (Varian SpectrAA10 and SpectrAA-20, Australia).

Alkalinity testing was done according to the standard method utilizing the potentiometer method. The sample was filtrated to overcome the effect of suspended solids on color and to detect point of change of color. The procedure for this method is described by Eaton et al. (2005).

\section{RESULTS AND DISCUSSION}

The main source of pond's water is both Wadi Hassan wastewater treatment plant and JUST wastewater treatment in addition to the precipitation, which is confined to short period in winter and spring. Fluctuation of water level at the pond reservoir is a combined result of an irregular variation of inflow and outflow. Water outflow from the reservoir increased during summer owing to an increasing demand of water for irrigation, in addition to evaporation. It is estimated that about 1700 $\mathrm{m}^{3} /$ daywater is pumped daily from the reservoir for agricultural uses in the campus. This wide fluctuation in water level, however, is a common feature in the reservoir and affects its ecology.

The physical and chemical analyses were done twice for the purpose of accuracy; in general, the standard errors did not exceed $5 \%$ for most of the analyses, which is considered acceptable in this work.

\section{A. Secchi Disc}

For station I, the mean Secchi depth at JUST pond was $32.5 \mathrm{~cm}$ with a minimum of $10 \mathrm{~cm}$ and a maximum of 90 $\mathrm{cm}$ as shown in Figure 2. The lowest measurements are obvious in summer season and the highest measurements are more pronounced in winter season. This is expected as in summer season the turbidity increases due to decomposition of algae, and in winter it decreases due to rainfall which washes up the pond.

\section{B. Temperature}

Mean ambient air and water pond temperatures of $20.75^{\circ} \mathrm{C}$ and $14.7^{\circ} \mathrm{C}$, respectively, were recorded over the sampling study period (one year). The greatest temperature of $31^{\circ} \mathrm{C}$ and $27^{\circ} \mathrm{C}$ for atmospheric and water pond, respectively, were noticed in June; while lowest of $11^{\circ} \mathrm{C}$ and $5^{\circ} \mathrm{C}$, respectively, in February. Temperature and nutrient are limiting factors of the growth rate of algae. Generally, the growth rate of algae increases with temperature increase.

\section{Dissolved Oxygen (DO)}

Results for dissolved oxygen as measured for different stations over different months are shown in Figure 3. Mean DO levels of $4.39 \mathrm{mg} / \mathrm{L}, 3.57 \mathrm{mg} / \mathrm{L}, 3.6 \mathrm{mg} / \mathrm{L}, 2.71$ $\mathrm{mg} / \mathrm{L}, 2.38 \mathrm{mg} / \mathrm{L}$ with minimum values of $3 \mathrm{mg} / \mathrm{L}, 2.6$ $\mathrm{mg} / \mathrm{L}, 2.6 \mathrm{mg} / \mathrm{L}, 1.7 \mathrm{mg} / \mathrm{L}, 1 \mathrm{mg} / \mathrm{L}$ and maximum values of $5.6 \mathrm{mg} / \mathrm{L}, 4.8 \mathrm{mg} / \mathrm{L}, 5.1 \mathrm{mg} / \mathrm{L}, 3.8 \mathrm{mg} / \mathrm{L}, 4.8 \mathrm{mg} / \mathrm{L}$ were determined for stations II-VI, respectively.

According toWHO (2006) and Jordanian guidelines (2006), DO should be greater than $2.0 \mathrm{mg} / \mathrm{L}$ and $1.0 \mathrm{mg} / \mathrm{L}$, respectively, for discharge to streams, valleys and water storage areas (Table 1). The concentrations of DO at the edge of the pond, effluent of Wadi Hassan wastewater treatment plant, influent of Wadi Hassan wastewater treatment to JUST pond, and JUST wastewater treatment plant are generally lie within the guidelines of WHO [9] and Jordanian guidelines [10] for wastewater reuse. However, the output from JUST pond exceeded the acceptable limits of WHO [9] and Jordanian guidelines [10] for ground water recharge for certain months; but still lie within Jordanian guidelines (2006) for discharge to streams, valleys and water storage areas $(1.0 \mathrm{mg} / \mathrm{L})$. This is because the water in the pond is stagnant and no aeration is provided. Figure 3 showed, in general, that DO decreases from low temperature season (winter) to high temperature season (summer). Such trend has been explained as a result of increased phytoplankton photosynthesis [11].

It has been noticed that DO concentration versus depth varies from one month to another. For example, in the month of September 2009, it ranged from 2.8 to $3.3 \mathrm{mg} / \mathrm{L}$ (Figure 4A); while for the month of April 2010, it ranged from 3.8 to $4.4 \mathrm{mg} / \mathrm{L}$ (Figure $4 \mathrm{H}$ ), and for the month of July 2010, it ranged from 2.0 to $3.7 \mathrm{mg} / \mathrm{L}$ (Figure 4L). Generally, DO decreases with increases depth; this is expected as oxygen solubility increase with the decrease in temperature and the increase in pressure. This is according to the empirical equation,

$$
D O=\frac{(P-p) \times 0.678}{35+t} .
$$

where, DO is dissolved Oxygen $(\mathrm{mg} / \mathrm{L}), \mathrm{P}$ is barometric pressure (torr), $\mathrm{p}$ is water vapor pressure (torr), and $\mathrm{t}$ is temperature $\left({ }^{\circ} \mathrm{C}\right)$.

The depletion of DO by the organic matter that accumulates in JUST pond during the summer season together with the increase of temperature resulted in the lower levels of DO.

\section{Nitrate}

Results for monthly measurement of nitrate $\left(\mathrm{NO}_{3}\right)$ for different stations are shown in Figure 5. Mean $\mathrm{NO}_{3}$ levels over one year cycle are $4.03 \mathrm{mg} / \mathrm{L}, 4.36 \mathrm{mg} / \mathrm{L}, 3.81 \mathrm{mg} / \mathrm{L}$, $38.65 \mathrm{mg} / \mathrm{L}, 3.05 \mathrm{mg} / \mathrm{L}$ with minimum values of 1.32 $\mathrm{mg} / \mathrm{L}, 0.88 \mathrm{mg} / \mathrm{L}, 0.88 \mathrm{mg} / \mathrm{L}, 11 \mathrm{mg} / \mathrm{L}, 4.4 \mathrm{mg} / \mathrm{L}$ and maximum values of $7.04 \mathrm{mg} / \mathrm{L}, 8.80 \mathrm{mg} / \mathrm{L}, 8.80 \mathrm{mg} / \mathrm{L}$, $91.9 \mathrm{mg} / \mathrm{L}, 4.4 \mathrm{mg} / \mathrm{L}$, were determined for stations II to VI, respectively.

The permissible limits for nitrate $\left(\mathrm{NO}_{3}\right)$ for different types of water according to $\mathrm{WHO}$ guidelines [9] Jordanian guidelines [10] are reported in Table 1 . The concentrations of $\mathrm{NO}_{3}$ at the edge of the pond, effluent of Wadi Hassan wastewater treatment plant, influent from Wadi Hassan wastewater treatment plant to the pond, and output from the JUST pond are generally lie within the guidelines of WHO [9] and Jordanian guidelines [10] for wastewater reuse. However, for JUST wastewater treatment plant, $\mathrm{NO}_{3}$ exceeded the acceptable limits of WHO [9] and Jordanian guidelines [10] for ground water recharge, effluent reuse for agricultural irrigation, cooked 
vegetables, parking areas, playgrounds and side of roads It can be stated that the high concentration of $\mathrm{NO}_{3}$ from inside cities, and plenteous trees and green areas, side of JUST treatment plant is diluted by mixing with JUST pond roads outside cities. But, such effluent lie within Jordanian water, particularly the amount of discharge from JUST Standards [10] for discharge to streams, valleys and water wastewater treatment plant is much smaller than that from storage areas $\mathrm{mg} / \mathrm{L}$, and field crops, effluent reuse for Wadi Hassan wastewater treatment plant. agricultural irrigation, industrial crops and forestry.

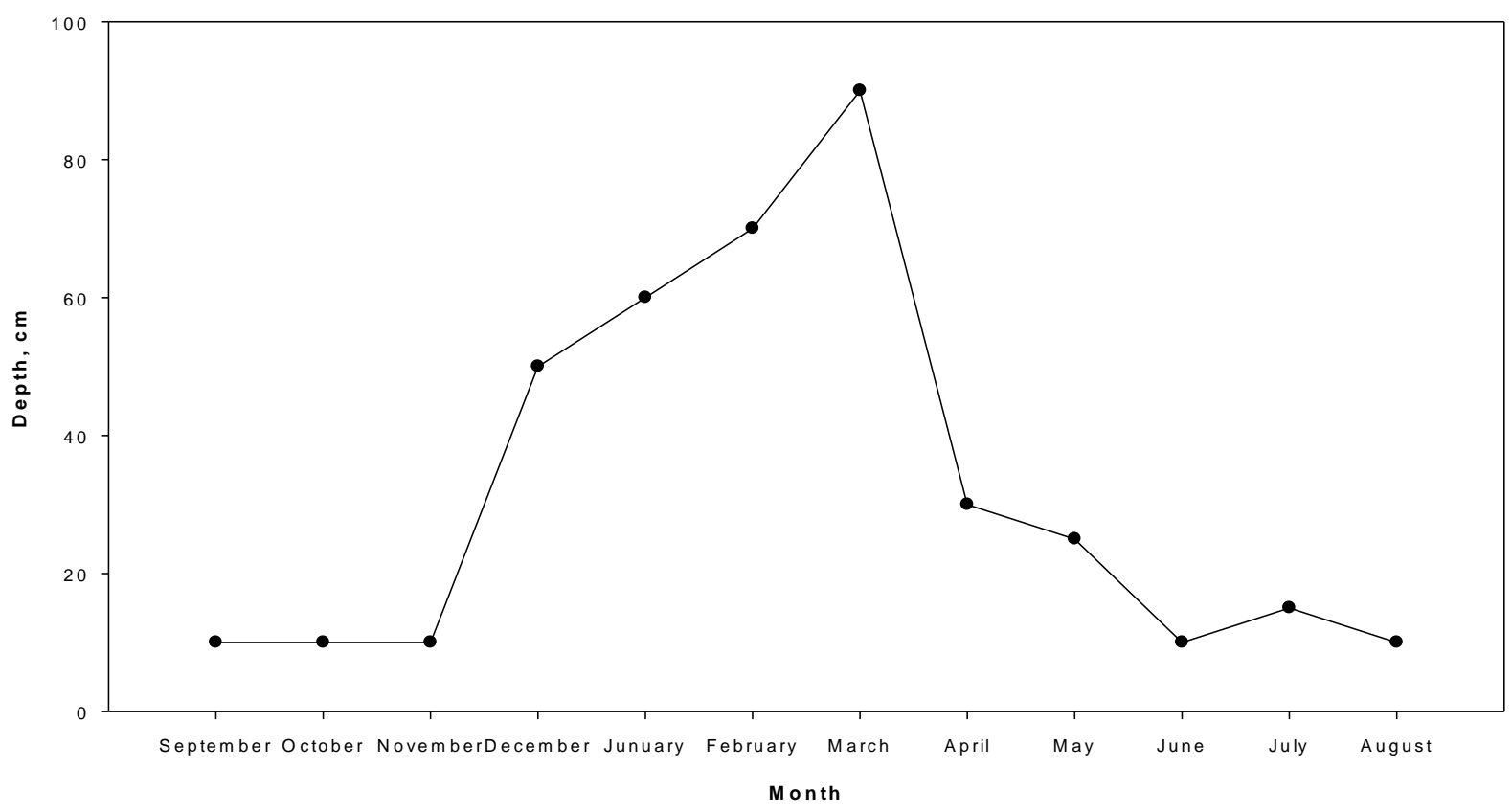

Figure 2: Secchi Disk depth versus different periods from September 2009 to August 2010.

Table 1: WHO and Jordanian guidelines for different parameters

\begin{tabular}{|c|c|c|c|c|c|c|c|c|c|}
\hline & \multicolumn{3}{|c|}{ WHO guidelines } & \multicolumn{6}{|c|}{ Jordanian guidelines } \\
\hline & \multirow[t]{2}{*}{ None } & \multirow{2}{*}{$\begin{array}{l}\text { Slight to } \\
\text { moderate }\end{array}$} & \multirow[t]{2}{*}{ Severe } & \multirow{2}{*}{ Limit 1} & \multirow{2}{*}{$\underset{* *}{\operatorname{Limit}} 2$} & \multicolumn{3}{|c|}{ Limit $3 * * *$} & \multirow{2}{*}{$\begin{array}{l}\text { Limit } \\
4 * * * *\end{array}$} \\
\hline & & & & & & A & $\mathrm{B}$ & $\mathrm{C}$ & \\
\hline TDS, mg/L & $<450$ & $450-2000$ & $>2000$ & 1500 & 1500 & & & & 1500 \\
\hline $\mathrm{Cl}, \mathrm{mg} / \mathrm{L}$ & $<142$ & $142-355$ & $>355$ & 350 & 350 & & & & 400 \\
\hline $\mathrm{NO} 3, \mathrm{mg} / \mathrm{L}$ & $<9.5$ & $91.5-518.5$ & $>518.5$ & 80 & 30 & 30 & 45 & 70 & \\
\hline $\mathrm{PO} 4, \mathrm{mg} / \mathrm{L}$ & & 15 & & 15 & 15 & & & & 30 \\
\hline $\mathrm{pH}$ & & $6.5-8.4$ & & $6-9$ & $6-9$ & $6-9$ & $6-9$ & $6-9$ & \\
\hline $\mathrm{DO}, \mathrm{mg} / \mathrm{L}$ & & $>2$ & & $>1$ & $>2$ & $>2$ & & & \\
\hline $\mathrm{Fe}, \mathrm{mg} / \mathrm{L}$ & & 5 & & 5 & 5 & & & & 5 \\
\hline $\mathrm{Mn}, \mathrm{mg} / \mathrm{L}$ & & 0.2 & & 0.2 & 0.2 & & & & 0.2 \\
\hline $\mathrm{Zn}, \mathrm{mg} / \mathrm{L}$ & & 2 & & 5 & 5 & & & & 5 \\
\hline $\mathrm{Cu}, \mathrm{mg} / \mathrm{L}$ & & 0.2 & & 0.2 & 1.5 & & & & 0.2 \\
\hline $\begin{array}{c}\text { E coli, } \\
\text { Col } / 100 \mathrm{ml}\end{array}$ & & 1000 & & 1000 & & 100 & 1000 & - & \\
\hline
\end{tabular}

* Discharge to streams, vallies and water storage areas.

** Ground water recharge.

*** Effluent reuse for agricultural irrigation; Cooked vegetables, parking areas, playgrounds and side of roads inside cities (A), Plenteous trees and green areas, side of roads outside cities (B) Field crops, industrial crops and forestry (C). ***** Effluent reuse for agricultural irrigation. 


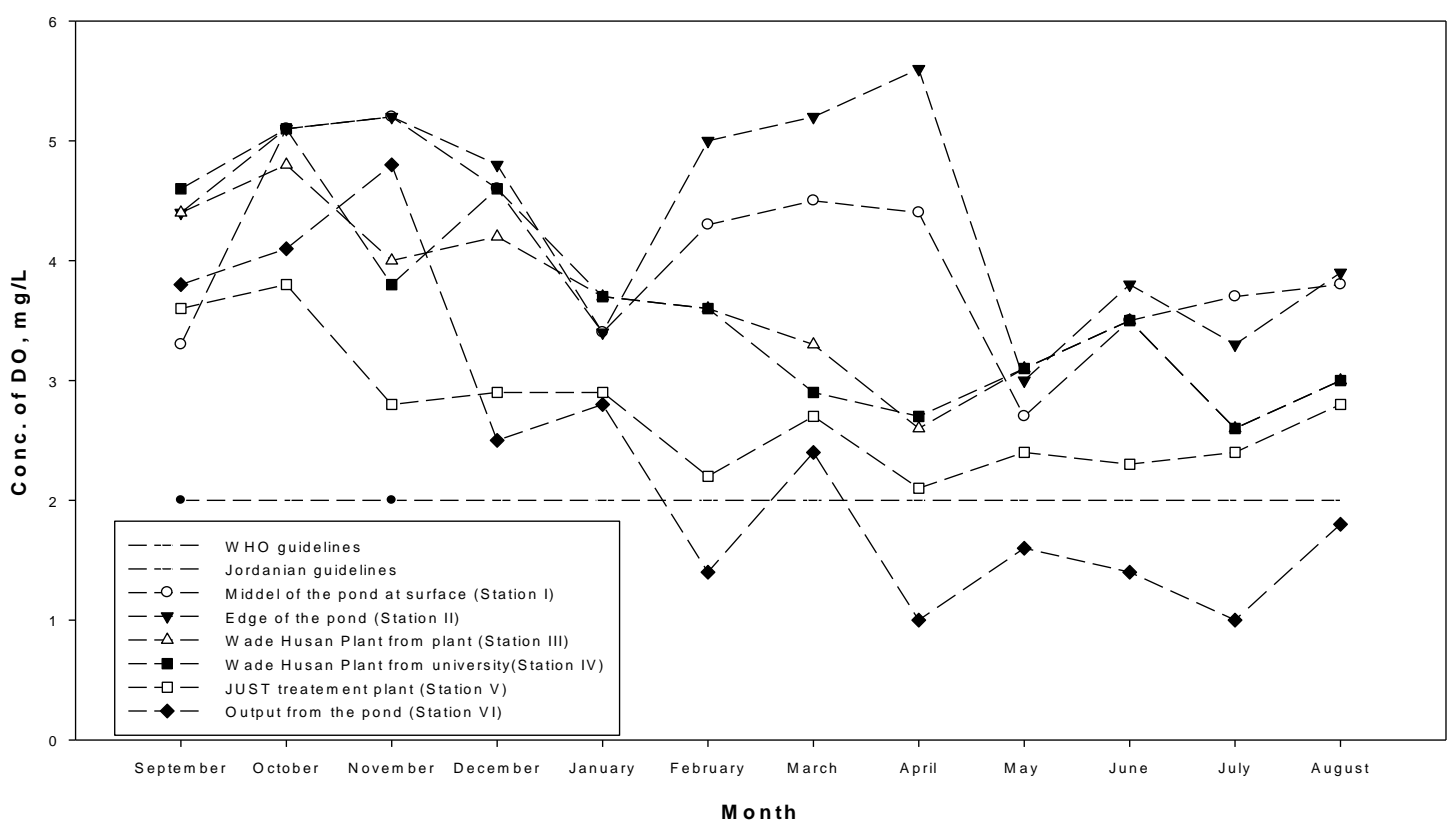

Figure 3: Monthly measurements of Dissolved Oxygen (DO) in different stations for the period of September 2009 to August 2010.

For station I, vertical profiles for $\mathrm{NO}_{3}$ are shown in Figure Changes in the levels of nutrients in the surface water are 6 for the period of September 2009 to August 2010, dominated by the inflows; while vertical profiles may have respectively. It is noticed that $\mathrm{NO}_{3}$ concentration varies in resulted from the exchange dynamics between the surface vertical direction from one month to another. For most water and the bottom water, i.e. stratification phenomenon. months, $\mathrm{NO}_{3}$ concentration increases as going from Progressive increase in $\mathrm{NO}_{3}-\mathrm{N}$ concentration with depth as surface of the pond to certain depth along vertical profile, observed in certain periods is possibly the result of the while it decreases for certain months. For example, for the oxidation of organic nitrogen in the descending seston (i.e. month of November 2009, $\mathrm{NO}_{3}$ ranged from 2.20 to 4.84 $\mathrm{mg} / \mathrm{L} \mathrm{NO}_{3}$ as going from the surface of the pond to a depth of $3 \mathrm{~m}$ (Figure $6 \mathrm{C}$ ); for the month of January 2010, $\mathrm{NO}_{3}$ ranged from 2.64 to $5.73 \mathrm{mg} / \mathrm{L} \mathrm{NO}_{3}$ as going from the surface of the pond to a depth of $5 \mathrm{~m}$ (Figure 6E); for the month of March 2010, $\mathrm{NO}_{3}$ ranged from 3.96 to 12.76 $\mathrm{mg} / \mathrm{L} \mathrm{NO}_{3}$ as going from the surface of the pond to a depth of $3 \mathrm{~m}$ (Figure $6 \mathrm{G}$ ); and so on for other months with different ranges and values. Such trend is expected since $\mathrm{NO}_{3}$ is heavier than water so it precipitates at the bottom of the pond. However, for the month of September 2009, $\mathrm{NO}_{3}$ ranged from 3.52 to $3.08 \mathrm{mg} / \mathrm{L} \mathrm{NO}_{3}$ as going from the surface of the pond to a depth of $3 \mathrm{~m}$ (Figure 6A); for the month of October 2009, $\mathrm{NO}_{3}$ ranged from 2.20 to 1.76 $\mathrm{mg} / \mathrm{L} \mathrm{NO}_{3}$ as going from the surface of the pond to depth of $3 \mathrm{~m}$ (Figure 6B); for the month of December 2009, $\mathrm{NO}_{3}$ ranged from 13.2 to $1.76 \mathrm{mg} / \mathrm{L} \mathrm{NO}_{3}$ as going from the surface of the pond to depth of $5 \mathrm{~m}$ (Figure 6D); and for the month of February 2010, $\mathrm{NO}_{3}$ ranged from 3.08 to $1.32 \mathrm{mg} / \mathrm{L} \mathrm{NO}_{3}$ as going from the surface of the pond to depth of $5 \mathrm{~m}$ (Figure 6F). The reason could be due to consumption of nitrate by algae, dilution by rain, wind, or withdrawal by output pump.

minute living organisms and particles of nonliving matter which float in water and contribute to turbidity). In many lakes of East Africa, for example, Lake Albert and Lake Victoria, high levels of $\mathrm{NO}_{3}-\mathrm{N}$ in deep layers have been described for situations where thermal stratification is pronounced, provided that deoxygenation is not too extreme [11]. Thus, the low levels of $\mathrm{NO}_{3}-\mathrm{N}$ near the reservoir bottom in certain periods of the year can be explained by the extreme bottom deoxygenation as evidenced by the low levels of DO near the bottom.

This is illustrated in Figure 7 which indicates that $\mathrm{NO}_{3}$ directly proportional with DO. The balance between the rate of seston accumulation at the hypolimnion and the rate of mineralization or recirculation to the epilimnion (i.e. fresh-water zone of relatively warm water in which mixing occurs as a result of wind action and convection currents) explains the profiles of total nitrogen.

\section{E. Phosphorus}

The results for phosphorus measurements at different stations over the one year cycle, September 2009 to August 2010, are shown in Figure 8. Concentration of phosphorus is expressed as total phosphorus $\left(\mathrm{T}-\mathrm{PO}_{4}\right)$. Leaching of nitrogen fertilizers, and discharge of Mean T-PO levels of $7.02 \mathrm{mg} / \mathrm{L}, 9.75 \mathrm{mg} / \mathrm{L}, 9.73 \mathrm{mg} / \mathrm{L}$, wastewater from Wadi Hassan treatment plant, and JUST $9.91 \mathrm{mg} / \mathrm{L}, 6.13 \mathrm{mg} / \mathrm{L}$ with minimum values of $1.50 \mathrm{mg} / \mathrm{L}$, treatment plant are likely responsible for nitrate content in $3.20 \mathrm{mg} / \mathrm{L}, 3.20 \mathrm{mg} / \mathrm{L}, 5.30 \mathrm{mg} / \mathrm{L}, \quad 1.70 \mathrm{mg} / \mathrm{L} \mathrm{and}$ the surface water. In addition, the decay of organic matter in the sediments at the bottom of the pond can be also a source for nitrate in the interstitial water.

maximum values of $15.30 \mathrm{mg} / \mathrm{L}, 15.90 \mathrm{mg} / \mathrm{L}, 15.90 \mathrm{mg} / \mathrm{L}$, $16.10 \mathrm{mg} / \mathrm{L}, 14.10 \mathrm{mg} / \mathrm{L}$, were detected for stations II-VI, respectively. 

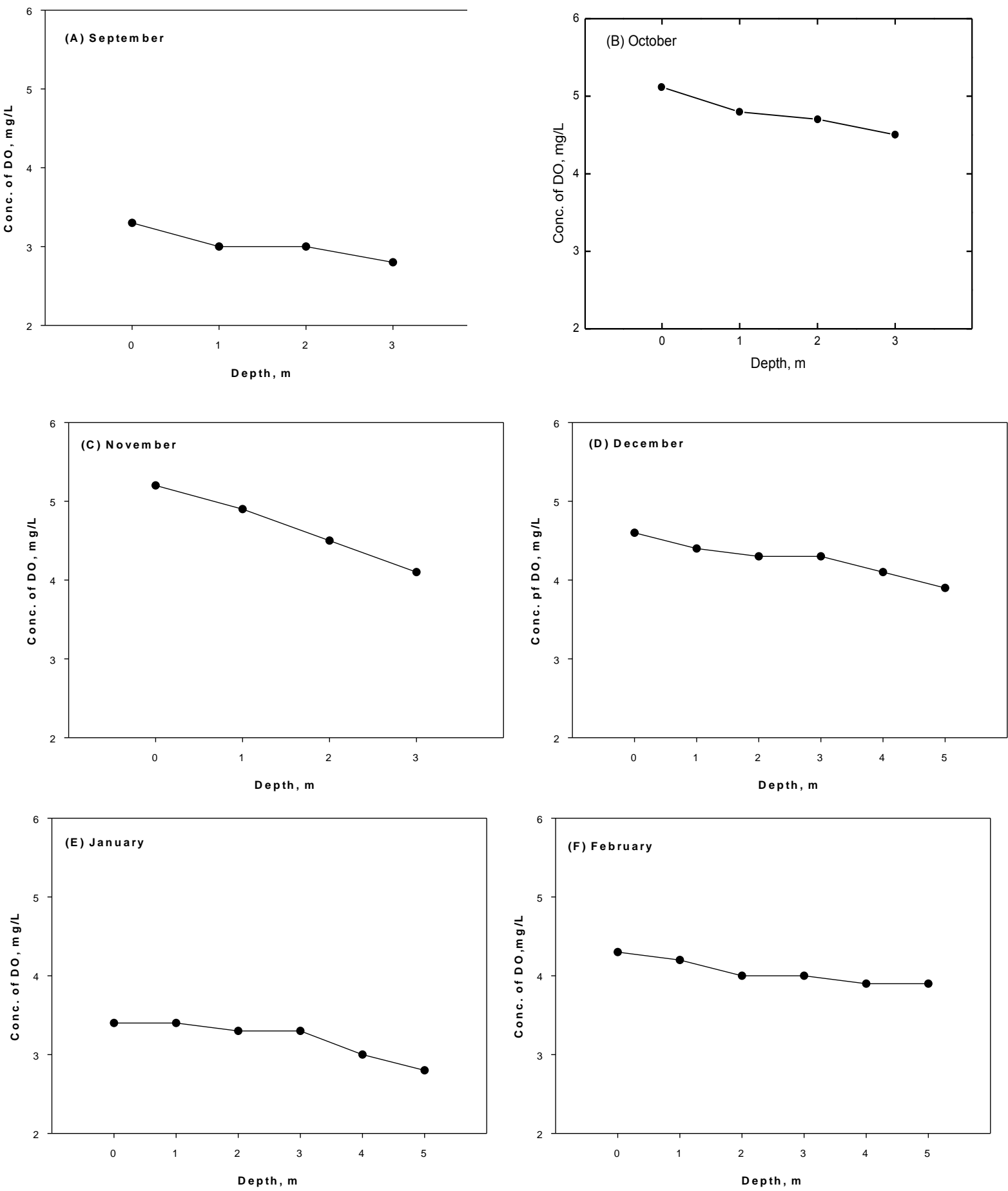

Figure 4: Vertical profiles of DO at the middle of JUST pond over the months of September 2009 to August 2010 (A to F).

The permissible limit for phosphorus $\left(\mathrm{T}-\mathrm{PO}_{4}\right)$ according to treatment to the pond, JUST wastewater treatment plant, WHO guidelines (2006) is $30 \mathrm{mg} / \mathrm{L}$ (Table 1). However, and output from the JUST pond are generally lie within according to the Jordanian guidelines [10] for discharge to the guidelines of WHO (2006) and Jordanian Standards streams, valleys and water storage areas, the permissible [10] for wastewater reuse, i.e. irrigation.

limit is $15.0 \mathrm{mg} / \mathrm{L}$, while for groundwater recharge it is $15.0 \mathrm{mg} / \mathrm{L}$, for agricultural irrigation it is $30 \mathrm{mg} / \mathrm{L}$ (Table $1)$.

Although the water level increases during winter which is expected to result in a decrease in the $\mathrm{T}-\mathrm{PO}_{4}$ concentration; but it has been noticed that there is an

It can be concluded that the concentrations of $\mathrm{T}-\mathrm{PO}_{4}$ at the edge of the pond, effluent from Wadi Hassan wastewater treatment plant, influent of Wadi Hassan wastewater increase in the amount of $\mathrm{T}-\mathrm{PO}_{4}$ in winter season. This might be due to the high rate of T- $\mathrm{PO}_{4}$ sedimentation, low movement of water, and probably the birds waste. 

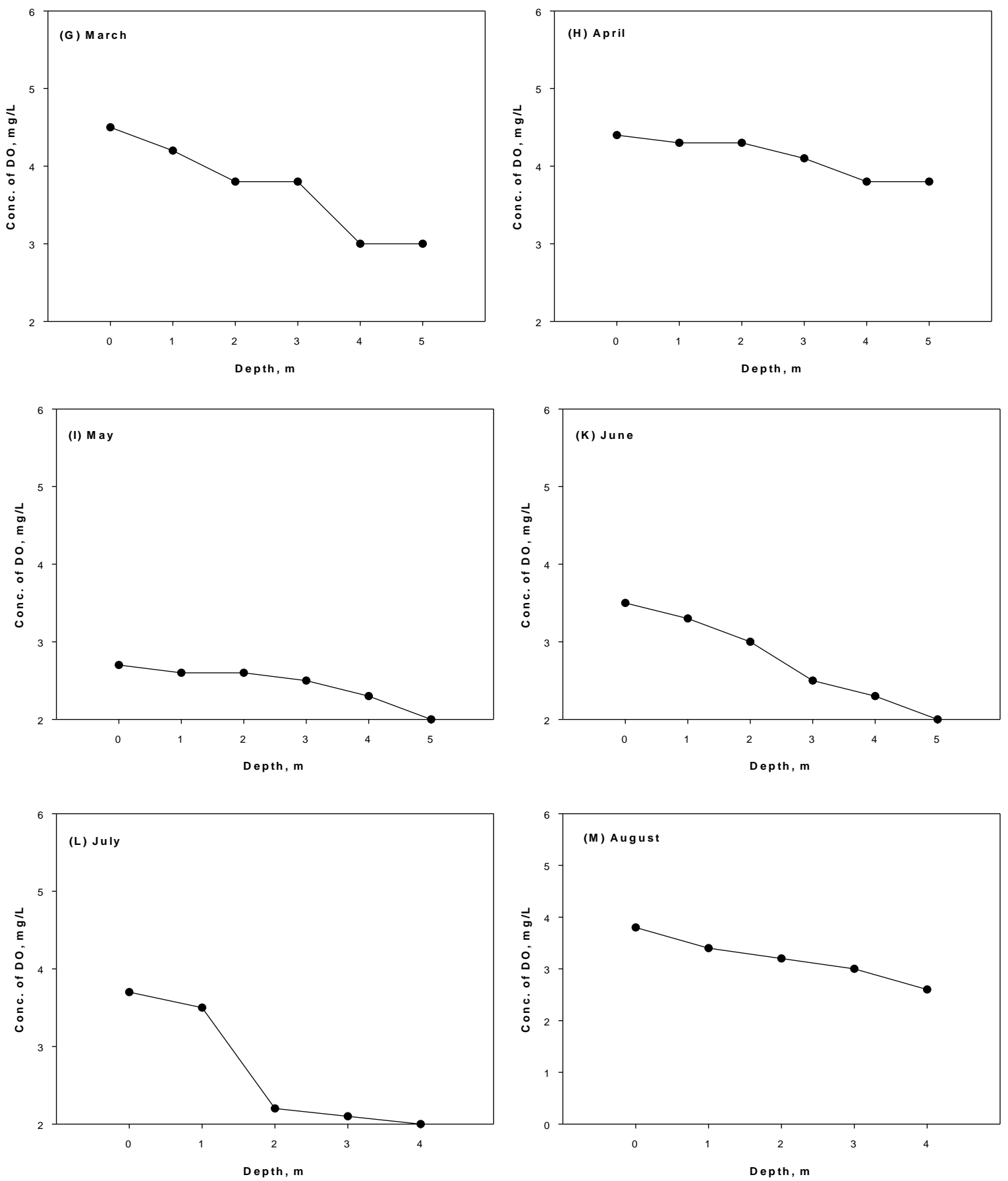

Figure 4: Vertical profiles of DO at the middle of JUST pond over the months of September 2009 to August 2010 (G to $\mathrm{M})$.

For station I, vertical profiles of $\mathrm{T}_{-} \mathrm{PO}_{4}$ as measured from depth of $5 \mathrm{~m}$ (Figure 9D); and for the month of January the surface of the pond to different depths are shown in 2010, only a slight change has been noticed (14.10 to Figure 9A for the period September 2009 to August 2010, $14.10 \mathrm{mg} / \mathrm{L}$ ) as going from the surface of the pond to a respectively. Generally, phosphate concentration with depth of $5 \mathrm{~m}$ (Figure 9E).

depth is either increasing or remain constant. For the Also, during the month of September 2009, phosphate month of October 2009, it increases from 5.20 to 5.40 remains almost constant. Such an increase in phosphate $\mathrm{mg} / \mathrm{L}$ as going from the surface of the pond to a depth of 3 could be due to the fact that $\mathrm{T}_{-} \mathrm{PO}_{4}$ been heavier than $\mathrm{m}$ (Figure 9B); for the month of November 2009, it water and it may precipitate at the bottom of the pond. In increases from 9.10 to $12.30 \mathrm{mg} / \mathrm{L}$ as going from the certain cases, slight reduction in $\mathrm{T}_{-} \mathrm{PO}_{4}$ were noticed (i. e. surface of the pond to a depth of $3 \mathrm{~m}$ (Figure 9C); for the February 2010) which could be attributed to $\mathrm{T}$ - $\mathrm{PO}_{4}$ month of December 2009, phosphate increases from 12.10 consumption by algae, dilution by rain, wind, and to $12.50 \mathrm{mg} / \mathrm{L}$ as going from the surface of the pond to a withdrawal by output pump. 


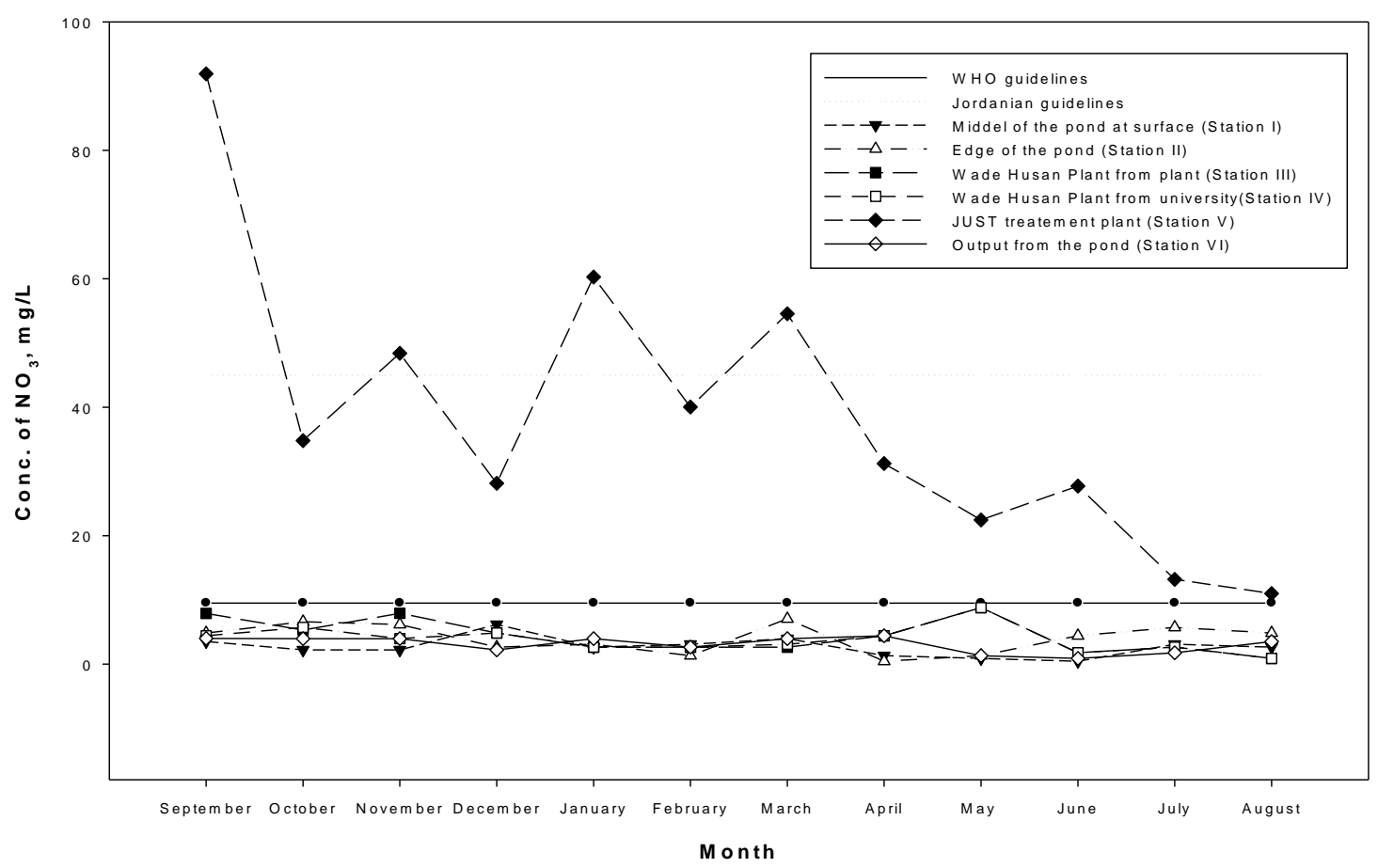

Figure 5: Monthly measurements of $\mathrm{NO}_{3}$ concentration in different stations for the period of September 2009 to August 2010.

Ruibiao and Huanting[12] studied similar case for $\mathrm{PO}_{4}$ but $\mathrm{mg} / \mathrm{L}, 5.0 \mathrm{mg} / \mathrm{L}$, and $0.2 \mathrm{mg} / \mathrm{L}$, respectively (Table 1). For with deeper pond, where he collected samples every 5 Fe concentration, all results lie within both WHO meters in depth. He concluded that low $\mathrm{PO}_{4}$ concentration guidelines [9] and Jordanian guidelines [10]. In regard to in the upper layer may be due to water mixing and $\mathrm{Zn}$, the results lie within Jordanian guidelines [10] and the phytoplankton's assimilation; while high $\mathrm{PO}_{4}$ average and minimum still lie within WHO guidelines [9] concentration in the bottom could be due to organisms but $\mathrm{Zn}$ has slightly exceeded the acceptable limits for such as plankton's body and excretion sink to the bottom. WHO guidelines [9]. For $\mathrm{Mn}$ and $\mathrm{Cu}$, the average and Another explanation for higher $\mathrm{PO}_{4}$ concentration at the minimum results still lie within both WHO guidelines [9] bottom might be due to sedimentation. According to and Jordanian guidelines [10], but the maximum exceeded Newton et al. [4] who studied the concentration of $\mathrm{PO}_{4}$ in the acceptable limits for both.

the sediment in the summer and winter seasons. They provide values to predict fluxes of phosphate across the sediment-water interface using Fick's first law of diffusion and found that phosphate is morereadily transferred to the water column under the reduced conditions of immersed sediment compared to the oxic conditions of sediment that has been flushed by tidal currents. However, the concentration of phosphate is much higher in the cores from the immersed sediments in both summer and winter.

\section{F. Heavy Metals}

Heavy metals including $\mathrm{Fe}, \mathrm{Mn}, \mathrm{Zn}$, and $\mathrm{Cu}$ were measured for all stations in this study. The average concentration of $\mathrm{Fe}, \mathrm{Mn}, \mathrm{Zn}$, and $\mathrm{Cu}$ were $0.418 \mathrm{mg} / \mathrm{L}$, $0.102 \mathrm{mg} / \mathrm{L}, \quad 0.272 \mathrm{mg} / \mathrm{L}, 0.084 \mathrm{mg} / \mathrm{L}$ with minimum concentration of $0.0 \mathrm{mg} / \mathrm{L}, 0.0 \mathrm{mg} / \mathrm{L}, 0.0 \mathrm{mg} / \mathrm{L}, 0.0 \mathrm{mg} / \mathrm{L}$ and with maximum concentration $4.98 \mathrm{mg} / \mathrm{L}, 0.97 \mathrm{mg} / \mathrm{L}$, $2.2 \mathrm{mg} / \mathrm{L}, 0.52$, respectively, as measured from September 2009 to April 2010. These results do not affect algae directly but it is important for water quality for irrigation.

The permissible limits for $\mathrm{Fe}, \mathrm{Mn}, \mathrm{Zn}$, and $\mathrm{Cu}$ according to WHO guidelines (2006) are $5.0 \mathrm{mg} / \mathrm{L}, 0.2 \mathrm{mg} / \mathrm{L}, 2.0$ $\mathrm{mg} / \mathrm{L}$, and $0.2 \mathrm{mg} / \mathrm{L}$, and according to Jordanian guidelines (2006) the permissible limit are $5.0 \mathrm{mg} / \mathrm{L}, 0.2$

G. $\mathrm{pH}$

The $\mathrm{pH}$ values for all stations are within the range 7.5-9.8 for the period September 2009 to April 2010. The permissible limits for $\mathrm{pH}$ according to both WHO [9] and Jordanian guidelines [10] are 6-9 (Table 1). It can be said that the measured $\mathrm{pH}$ values are in the upper range of the permissible limit, with values lying in the basic range resulting in a slightly alkaline media. It can be said that $\mathrm{pH}$ values in summer season were larger than winter season.

\section{H. Alkalinity}

The alkalinity values for all stations are within the range 180-820 mg/L for the period September 2009 to April 2010. The permissible limits for alkalinity according to both WHO [9] and Jordanian guidelines [10] are $400 \mathrm{mg} / \mathrm{L}$ (Table 1). It can be said that all measured alkalinity values are in the upper range of the permissible limit except for very few cases, with values lying in the basic range resulting in a slightly alkaline media. The high concentration of bicarbonate $\mathrm{HCO}_{3}^{-}$may be attributed to the reaction between both calcium and magnesium carbonate and carbonic acid and probably due to dissociation of calcium and magnesium carbonate. 

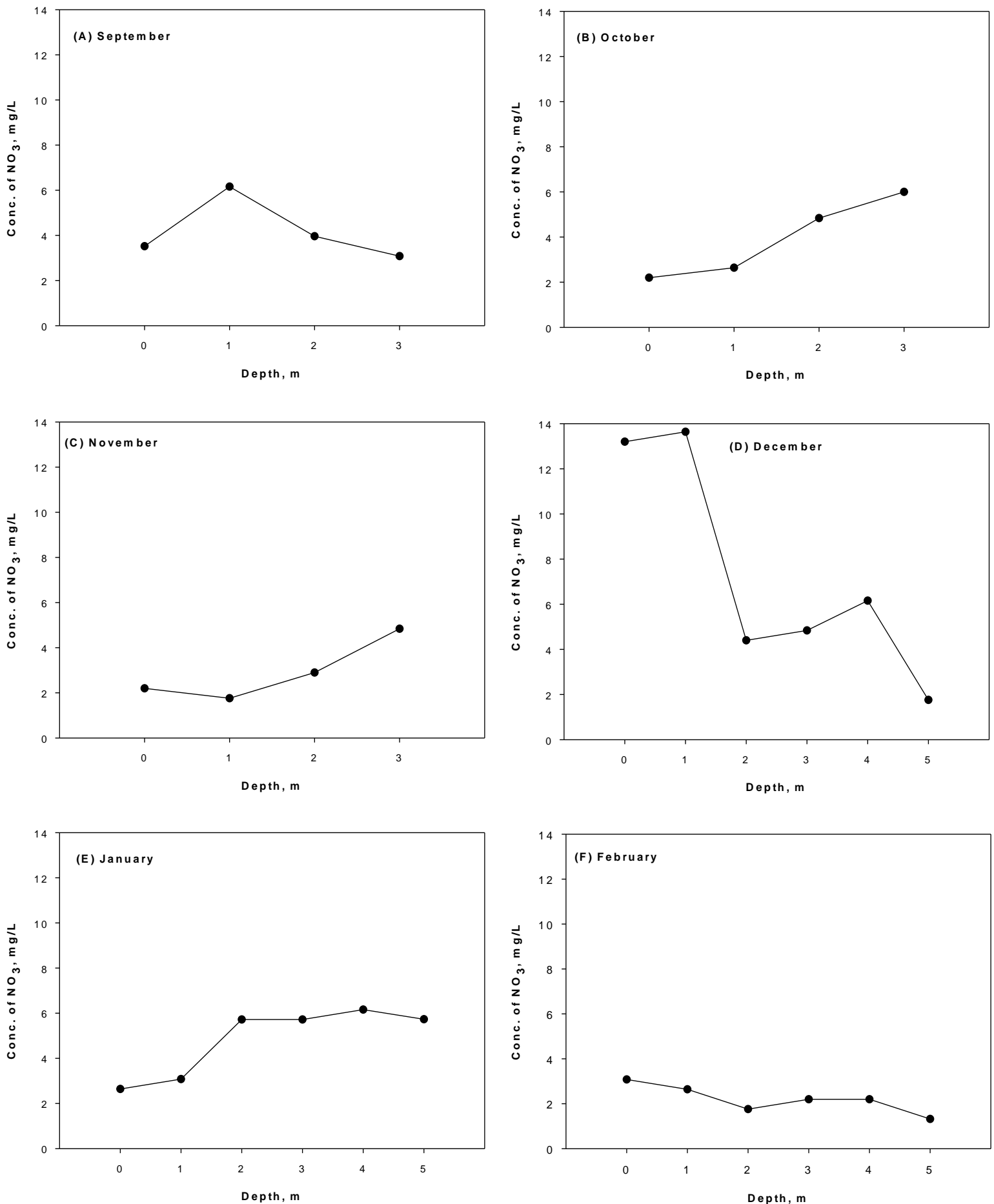

Figure 6: Vertical profiles of $\mathrm{NO}_{3}$ concentration at the middle of JUST pond over the months of September 2009 to August 2010 (A to F).

I. Chloride

The permissible limits for chloride according to WHO guidelines [9] are reported as a potential irrigation problem and as degree of restriction on use as follows (Table 1): none $<142.0 \mathrm{mg} / \mathrm{L}$, slight to moderate 142.0 $355.0 \mathrm{mg} / \mathrm{L}$, and severe > $355.0 \mathrm{mg} / \mathrm{L}$. However, according to Jordanian guidelines [10], for effluent reuse such as agricultural irrigation the permissible limit is 400.0 $\mathrm{mg} / \mathrm{L}$ (Table 1). Chloride measurements for all stations lie within the slight to moderate range according to WHO[9]. Most readings are within the ranges $275-320 \mathrm{mg} / \mathrm{L}$ except for very few cases where the measurements exceeded that of WHO[9] upper limit but still below the upper limit according to Jordanian guidelines [10]. As expected, the presence of chloride is due to addition of chloride to water during treatment steps in both Wadi Hassan wastewater treatment plant and JUST wastewater treatment plant in the of disinfection. 

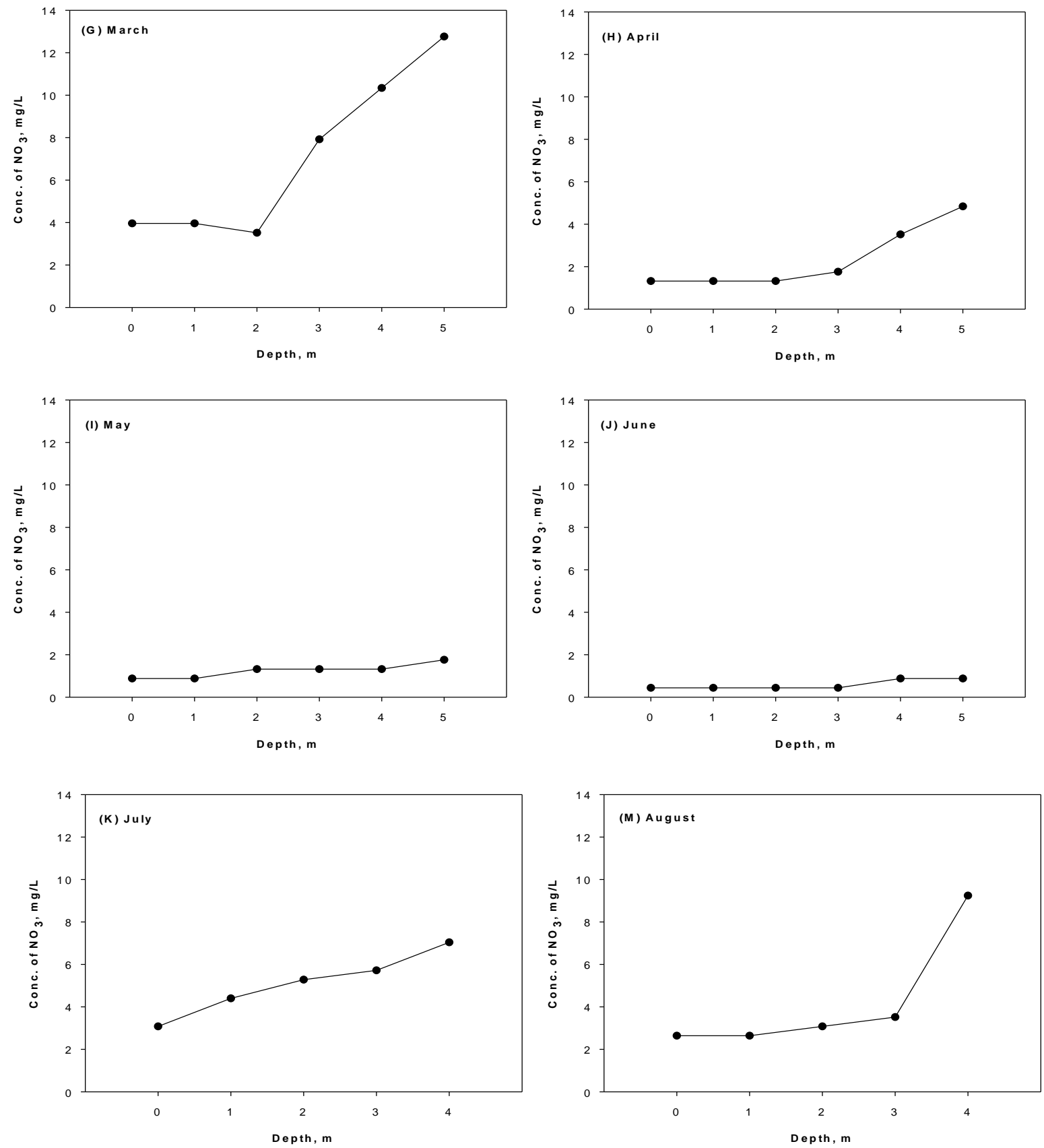

Figure 6: Vertical profiles of $\mathrm{NO}_{3}$ concentration at the middle of JUST pond over the months of September 2009 to August 2010 (G to M).

J. Total Dissolved Solids (TDS)

The permissible limits for Total Dissolved Solids (TDS) according to WHO guidelines [9] are reported as a potential irrigation problem and as degree of restriction on use are as follows: none $<450 \mathrm{mg} / \mathrm{L}$, slight to moderate $450-2000 \mathrm{mg} / \mathrm{L}$, and severe $>2000 \mathrm{mg} / \mathrm{L}$.

According to Jordanian guidelines [10] the permissible limit for Total Dissolved Solids (TDS)is $1500 \mathrm{mg} / \mathrm{L}$ (Table 1). According to the measurement performed in this work for TDS over the study period, most of the TDS values are within the slight to moderate range in respect to WHO guidelines [9] and always less than upper limit of Jordanian guidelines [10].

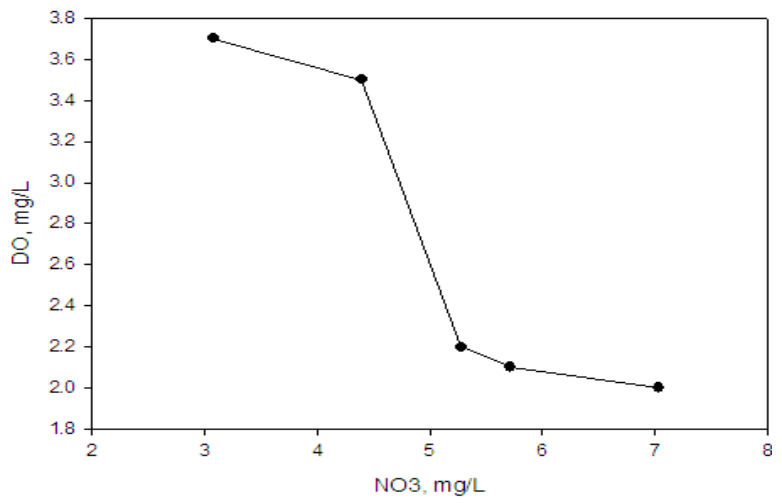

Figure 7: Relationship between $\mathrm{DO}$ and $\mathrm{NO}_{3}$ on different depth ranging 0-4 m during June, 2010. 
K. Electrical Conductivity (EC)

The average value of electrical conductivity (EC) for all stations is $1536 \mu \mathrm{S} / \mathrm{cm}$ (microsiemens per centimeter) over the entire period, minimum value of $1071 \mu \mathrm{S} / \mathrm{cm}$ for station $\mathrm{V}$ for the month of June 2010, and maximum value of $2003 \mu \mathrm{S} / \mathrm{cm}$ for station III for the month of May 2010, was recorded.
The permissible limits for electrical conductivity (EC) according to WHO guidelines [9] are reported as a potential irrigation problem and as degree of restriction on use are as follows: none $<700 \mu \mathrm{S} / \mathrm{cm}$, slight to moderate $700-3000 \mu \mathrm{S} / \mathrm{cm}$, and severe $>3000 \mu \mathrm{S} / \mathrm{cm}$. It is seen that all results from all stations are within the slight to moderate range according to WHO guidelines [9].

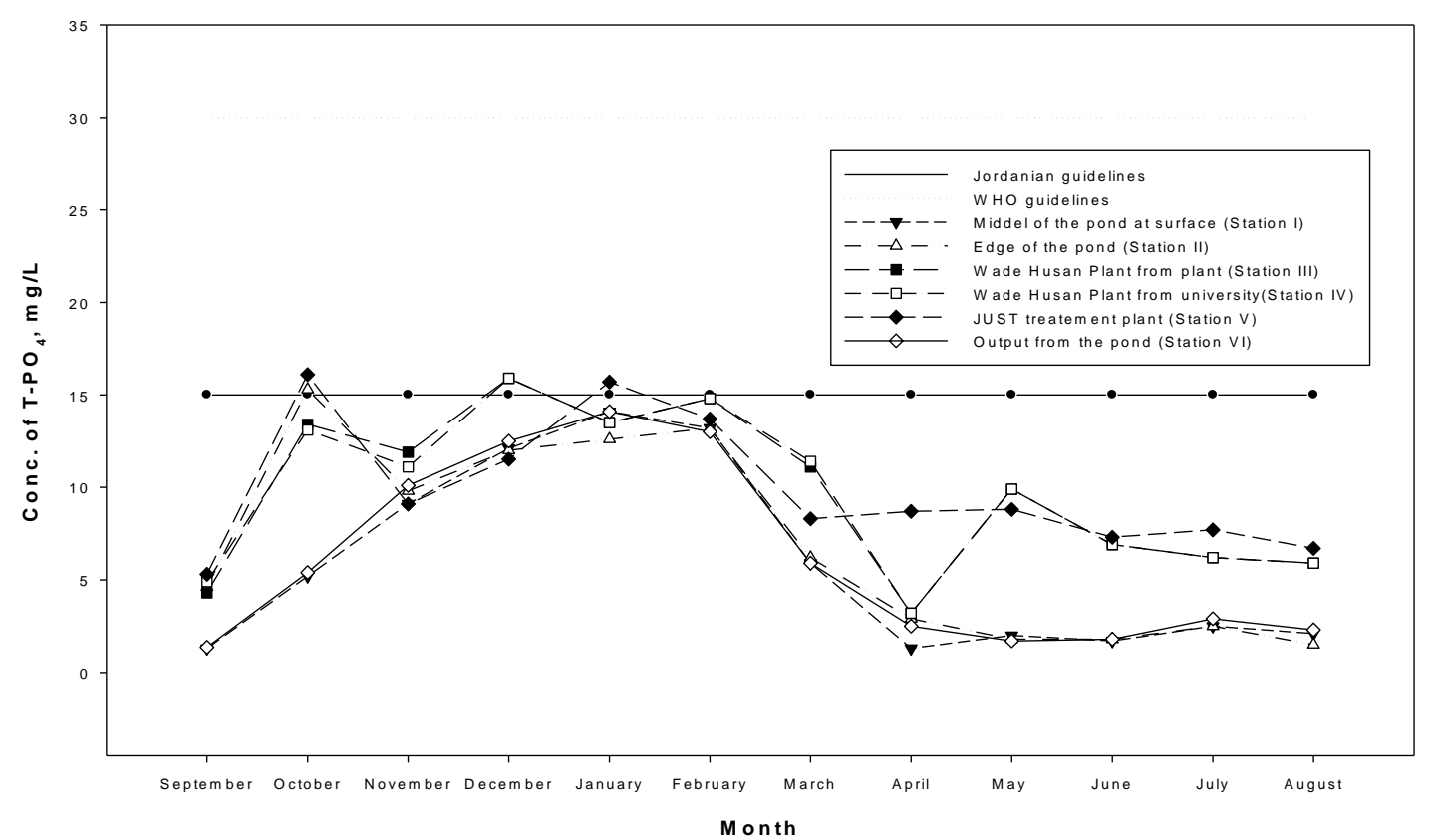

Figure 8: Monthly measurements of T-PO $\mathrm{PO}_{4}$ in different stations over the period of September 2009 to August 2010.

L. Chemical Oxygen Demand (COD)

The average values of chemical oxygen demand (COD) were measured for stations II, III, and V is $54.005 \mathrm{mg} / \mathrm{L}$ over the entire period; minimum of $16 \mathrm{mg} / \mathrm{L}$ for station $\mathrm{V}$ for the month of November 2009, and with maximum of $160 \mathrm{mg} / \mathrm{L}$ for station II for the month of October 2009, were recorded. The permissible limits for Electrical Conductivity (EC) according to Jordanian guidelines [10], for discharge to streams, valleys and water storage areas the permissible limit for COD is $150 \mathrm{mg} / \mathrm{L}$; for ground water recharge, it is $50 \mathrm{mg} / \mathrm{L}$; for effluent reuse such as agricultural irrigation, cooked vegetables, parking areas, playgrounds and side of roads inside cities, it is $100 \mathrm{mg} / \mathrm{L}$; plenteous trees and green areas, side of roads outside cities, it is $500 \mathrm{mg} / \mathrm{L}$; and for field crops, industrial crops and forestry, it is $500 \mathrm{mg} / \mathrm{L}$. It can be said that all results from stations II, III, and V lie within the acceptable range.

\section{Pond Sediments}

Samples from the sediment of the pond were collected and analyzed on May 2009. Results for various parameters considered are shown in Table 2. Values for $\mathrm{NO}_{3}$ of 24.2 $\mathrm{mg} / \mathrm{L}$, phosphorus of $12.6 \mathrm{mg} / \mathrm{L}$, dissolved oxygen of 3.6 $\mathrm{mg} / \mathrm{L}, \mathrm{pH}$ of 7.8 , TDS of $655 \mathrm{mg} / \mathrm{L}$, chloride of $8 \mathrm{mg} / \mathrm{L}$, EC of 1458 of $\mu \mathrm{S} / \mathrm{cm}$, and COD of $51.6 \mathrm{mg} / \mathrm{L}$, were detected. All of these values lie within both WHO guidelines [9] and Jordanian guidelines [10]. But for $\mathrm{Zn}$ and $\mathrm{Mn}$, concentrations of $10.35 \mathrm{mg} / \mathrm{L}$ and $0.23 \mathrm{mg} / \mathrm{L}$, were detected, respectively, which exceeded the acceptable limits for both WHO guidelines [9] and Jordanian guidelines [10].

Comparing the above mentioned parameters as measured in sediment with those of water surface, it can be seen that the values for all parameters are higher in the sediment than that in the water surface except for $\mathrm{pH}$, TDS, and DO. These are expected results as such compounds, described in Table 2, settle at the bottom of the pond and resulted in concentrated media.

N. Water Quality Management for JUST Pond

The following remarks are proposed as options and scenarios for better water quality management for JUST pond:

1. A systematic sampling program with sufficient samples frequency is recommended; this include the important parameters referred to water quality such as dissolved oxygen, $\mathrm{pH}$, ammonia, temperature, alkalinity, hardness, hydrogen sulfide, phosphorus, salinity, biological oxygen demand, turbidity, chemical oxygen demand, secchi disk, and E coli.

2. Because the input from JUST wastewater treatment plant exceeded the acceptable guidelines limits for $\mathrm{NO}_{3}$ concentration, it is recommended to implement nitrification/dentrification unit to reduce $\mathrm{NO}_{3}$ concentration.

3. Storage tanks and flow management for water is suggested. This is particularly needed when $\mathrm{NO}_{3}$ 
concentration for JUST wastewater treatment plant exceeded the permissible limit and this could help to avoid overconcentration in the pond. In addition, such water collected in the tanks can undergo nitrification/dentrification process when needed.

4. Because of high level of $\mathrm{NO}_{3}$ and $\mathrm{PO}_{4}$ in samples from JUST wastewater treatment plant, it is advisable to locate the main source for such compounds in the campus, academic units, housing, hospital, etc. This is referring to sampling from different manholes in the campus.
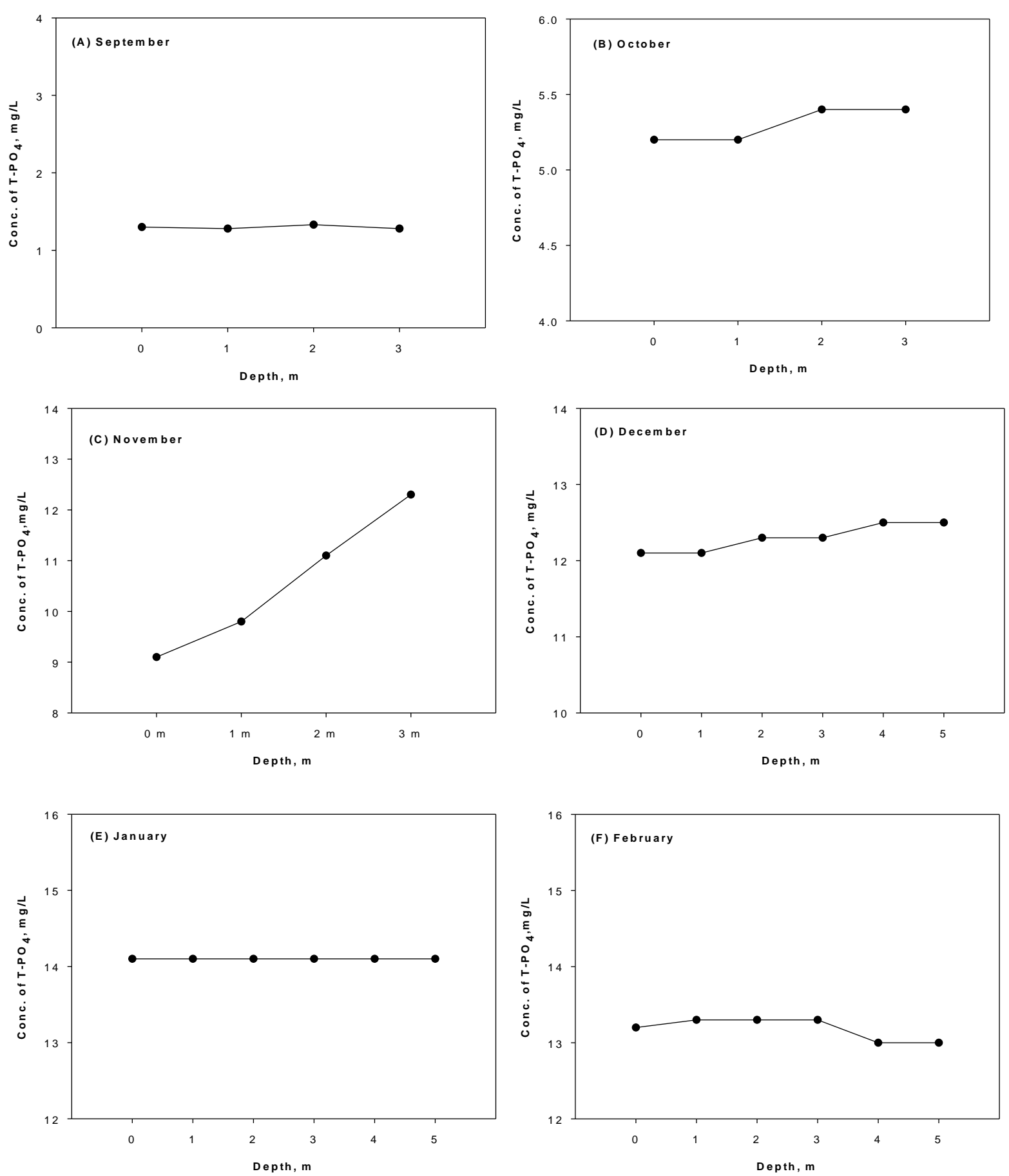

This might be followed by management of such water before sending it to JUST wastewater treatment plant.

5. Both input from Wadi Hassan wastewater treatment plant and input from JUST wastewater treatment plant reach the limits border for $\mathrm{PO}_{4}$ concentration. Thus, removal of phosphate by using chemical control in the plants is suggested. For example, calcium hydroxide can be used as it is capable of removing phosphate completely.

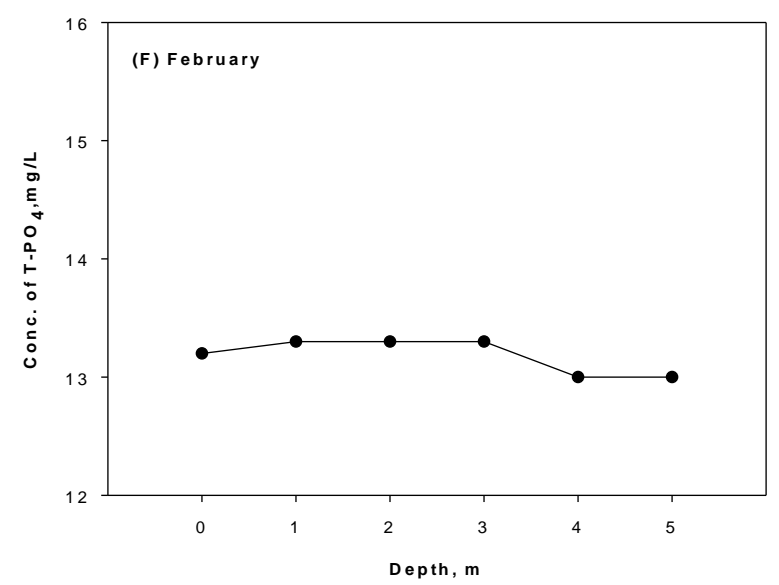

Figure 9: Vertical profiles of T- $\mathrm{PO}_{4}$ concentration at the middle of JUST pond over the months of September 2009 to August 2010 (A to F). 

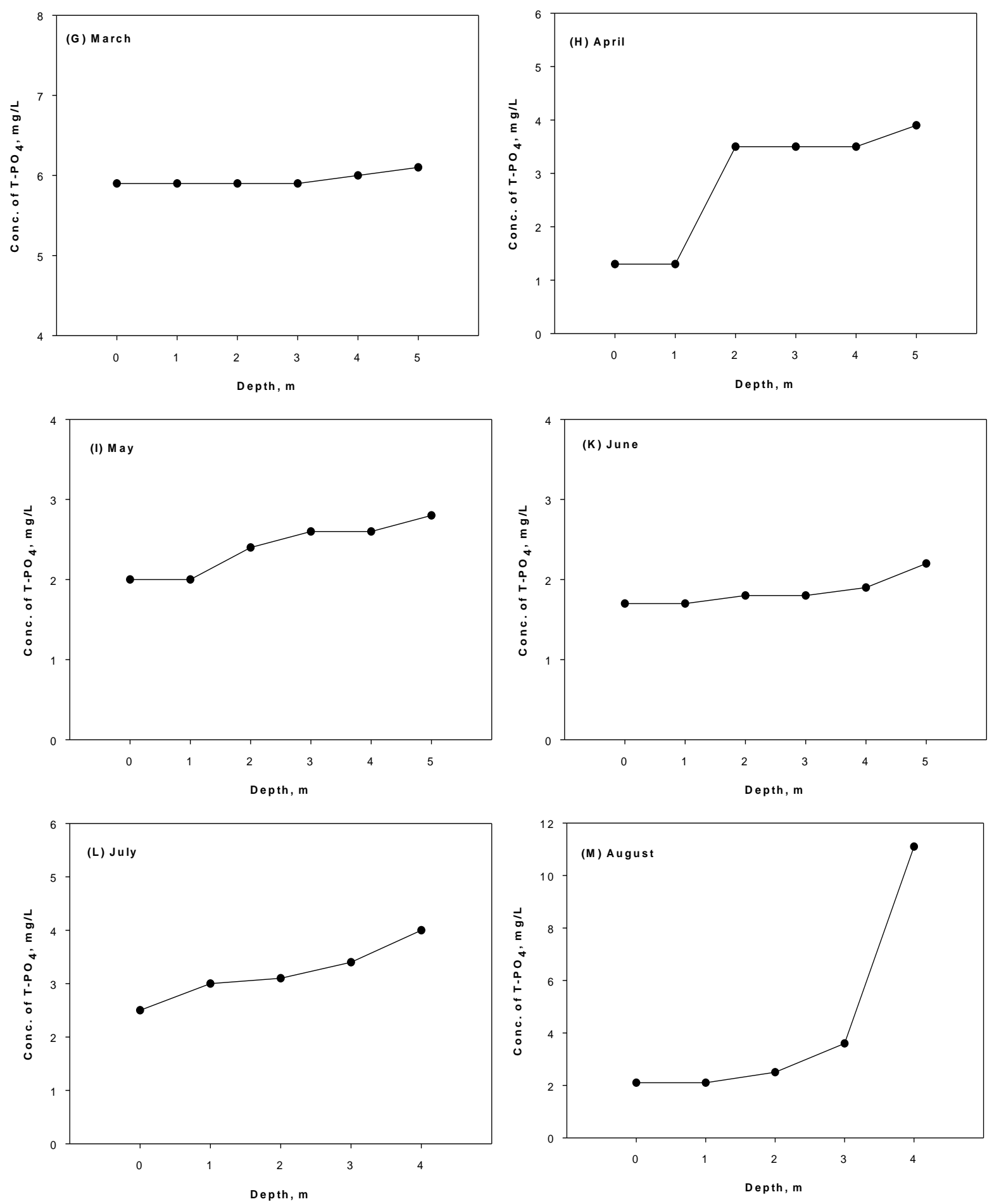

Figure 10: Vertical profiles of T-PO 4 concentration at the middle of JUST pond over the months of September 2009 to August 2010 (G to M).

6. Sub-surface aeration greatly improves water quality by increasing dissolved oxygen levels, destratifing the water column and improving circulation. Aeration is known to reduce algae growth by providing the oxygen necessary for aerobic bacteria digestion of nitrites, reverse aging and degradation, improve clarity, production and capacity; reduce the buildup of pollutants; and keep water open year-round for wildlife.
Thus, it is suggested to design reasonable aeration system in the pond.

7. Use of barley straw has been suggested to prevent growth of algae in ponds. The straw can be applied loosely or in cages at several locations in the fall or spring. It is important to note that barley straw does not kill existing algae, but it prevents its growth [13], thus is recommended to apply it before appearance of algae. 


\section{CONCLUSION}

Based on the results presented, a set of conclusion remarks were drawn. Pond water is clear in winter compared to summer. Results of $\mathrm{PO}_{4}$ and $\mathrm{NO}_{3}$ values for all stations lie within both WHO and Jordanian guidelines. Sometimes in winter season both effluents from Wadi Hassan wastewater treatment plant and JUST wastewater treatment plant reach the upper permissible limit for phosphate. For NO3 values for some cases; the input from JUST wastewater treatment plant exceeded the acceptable limits. Results of all stations for dissolved oxygen lie within the guidelines except for the output from the JUST pond which exceeded the acceptable limits. Results for the parameters related to the sediment of the pond lie within guidelines except for $\mathrm{Zn}$ and $\mathrm{Mn}$ which slightly exceeded the acceptable limits.

\section{REFERENCES}

[1] Smith V. H. \& Gene E. L. (2009) Eutrophication. Encyclopedia of Inland Waters. Oxford, Academic Press.

[2] Malberg J. W. \& Savage E. P. (1978) Nitrates in Drinking Water and the Early Onset of Hyperstencion Environ Pullut, 15, 155-160.

[3] Zevenboom W., Bij de vaate A. \& Mur L.R. (1982) Assessment of Factors Limiting Growth Rate of OscillatoriaAgardhii in Hypertrophic Lake Wolderwijd, 1978, By Use Of Physiological Indicators. Limnol.Oceangr, 27, 39-52.

[4] Newton A., Icely J. D., Falcao M., Nobre A., Nunes J. P., Ferreira J. G. \& Vale C. (2003) Evaluation of Eutrophication in the Ria Formosa Coastal Lagoon, Portugal. Continental Shelf Research, 23, 1945-1961.

[5] Sawyer C. N. (1966) Basic Concepts of Eutrophication. J. Wat. Pollut. Cont. Fed, 38, 737-744.

[6] Mackenthum K. M. (1962) A Review of Algae, Lake Weeds and Nutrients. J. Water Pollut. Control Fed., 34, 1077-1085.

[7] Spears B. M., Carvalho L., Perkins R. \& Paterson D. M. (2008) Effects of Light on Sediment Nutrient Flux and Water Column Nutrient Stoichiometry in a Shallow Lake. Water Research, 42, 977-986.

[8] Beutel M. W., Leonard T. M., Dent S. R. \& Moore B. C. (2008) Effects of Aerobic and Anaerobic Conditions on P, N, Fe, Mn, And $\mathrm{Hg}$ Accumulation in Waters Overlaying Profundal Sediments of an Oligo-Mesotrophic Lake. Water Research, 42, 1953-1962.

[9] WHO (2006) A Compendium of Standards for Wastewater Reuse in the Eastern Mediterranean Region. World Health Organization.

[10] Jordanian (2006) Water - Reclaimed Domestic Wastewater. Jordanian Standard.

[11] K. K. \&Muthuri M. M. (1998) Temporal Changes in Phytoplankton Structure and Composition at Turkwel Gorge Reservoir, Kenya. Hydrobiologia, 368, 41-59.

[12] Ruibiao F. \&Huanting S. (2002) Biogeochemical Character of Dissolved Inorganic Nitrogen and Phosphate at Plume Front in the Changjiang River. Marine Science Bulletin, 4, (2), 25-31.

[13] Caffrey J.M. and Monahan C. (1999) Filamentous Algal Control using Barley Straw.Hydrobiologia, 415, 315-318. 